\title{
Mortality in the British printing industry: a historical cohort study of trade union members in Manchester
}

\author{
D A Leon
}

\begin{abstract}
A historical cohort study of the printing industry was established after an anecdotal report of a cluster of cases of bladder cancer in a newspaper factory in Manchester. The cohort comprised some 9500 men who were members of one or other of two trade unions (the NGA and NATSOPA) in the Manchester area between 1949 and 1963. During the follow up period (1949-83) 3482 deaths occurred among men born in 1890 or later; follow up was $97 \%$ complete.
\end{abstract}

The results of the study do not support the hypothesis of an occupational risk of bladder cancer in the printing industry. The NGA have a standardised mortality ratio (SMR) of 63 (95\% confidence interval (95\% CI 31-113) and NATSOPA an SMR of 113 (95\% CI 67-178) based on 11 and 18 deaths from bladder cancer, respectively. Men involved in newspaper letterpress printing have a high mortality from lung cancer (SMR = 179, 95\% CI 144-218) that is consistent with the findings of previous studies. Increased mortality from cancer of the buccal cavity and pharynx was found for NATSOPA workers in the newspaper industry; editorial workers had an SMR of 1053 (95\% CI 128-3803) and clerical workers had an SMR of 638 (95\% CI 132-1864). This is consistent with a review of published studies, which strongly suggest that workers in the printing industry have an increased risk of mortality from cancers of the buccal cavity and pharynx. Socioeconomic differences in union composition, rather than occupational factors, may account for the lower mortality in the NGA compared with NATSOPA. The NGA, a craft union, had an all causes SMR of $92(95 \%$ CI 88-97), whereas NATSOPA covered a broader span of occupations and skill levels, and had an all causes SMR of 112 (95\% CI 106-117); the NATSOPA and NGA all causes rate ratio was $1.21 \quad(95 \%$ CI 1.13-1·29).

(Occup Environ Med 1994;51:79-86)

In early 1979, trade unionists in a Manchester newspaper printing plant became concerned about a possible cluster of cases of bladder cancer. Investigations showed the occurrence of three cases diagnosed between
1971 and 1979, compared with about 0.7 expected on the basis of national rates. The fact that these cases were among van drivers (rather than production workers), did not undermine the plausibility of an occupational link as until 1967 air extracted from the printing machine room of the factory had been discharged into the covered van loading bay.

At the time, little was known about risks of cancer in the printing industry. Three case control studies had reported on the risk of bladder cancer associated with working in the industry relative to other industries, ${ }^{1-3}$ none of which had shown an increased risk. One proportional mortality study had suggested an increased risk of bladder cancer among men working in general print (those sections of the industry other than newspaper printing-for example, magazines, books, packaging). ${ }^{4}$ Excesses of cancers of the lung, ${ }^{5-7}$ buccal cavity, pharynx, rectum, and pancreas among print workers had also been reported. ${ }^{7}$

There was toxicological evidence of the mutagenic and carcinogenic potential of some materials used in the industry. ${ }^{89}$ Also there was documented evidence that up until the mid 1970s, a known human bladder carcinogen (4-aminodiphenyl) had been present in some printing inks manufactured and used in Britain. ${ }^{10}$

In summary, the epidemiological data that existed at the beginning of the 1980s was sparse, lacked statistical power and was of questionable validity. No cohort studies had been reported, the evidence that did exist rested upon a few, methodologically weaker, proportional mortality studies, supplemented by a few case-control studies. Only two of the studies had been conducted in Britain. ${ }^{56}$ There was a need for a more powerful, better designed, and comprehensive study of the effects on health, of work in the British printing industry, particularly with respect to risk of cancer. This led to the establishment of the mortality cohort study, the design and results of which are described here.

Subjects and methods

The cohort was derived from the membership records of the Manchester branches of two printing trade unions-the National Graphical Association (NGA) and the National Society of Operative Printers, Graphical, and Media Personnel (NATSOPA) - both of which have now been subsumed into a single union in a series of amalgamations. Manchester was

\footnotetext{
Accepted for publication 5 April 1993 Epidemiology and London School of Medicine, Keppel

Street, London WC1E 7HT

D A Leon
} 
chosen as the location principally because it was unique as a well defined area that contained the full diversity of sectors of the printing industry, from newspapers to small scale general print operations. Trade union membership records were an appropriate source for the cohort; historically trade unions in the printing industry had played a key part in the regulation of labour, and until recently, most people working in the industry had belonged to a trade union, particularly in newspaper printing. ${ }^{11}$

The NGA and NATSOPA branches were selected after a pilot study of all printing trade union branches in Manchester. These were the only branches that had kept complete and detailed membership records from the early part of the century. These were in the form of card indices and nominal lists and membership ledgers. The branch from which the initial report of a cluster of cases of bladder cancer originated was not included as it had not kept records on retired or dead members. Women were not included in the cohort as neither the NGA nor NATSOPA branches had substantial female membership. The NGA (previously the Typographical Association $^{12}$ ) was the craft union of the industry, a lengthy apprenticeship having to be served before full membership was awarded. NATSOPA covered a more diverse range of occupation ${ }^{13}$ that were generally less skilled and of lower status than those covered by the NGA.

Men were eligible for inclusion in the cohort if they had been full time members of the Manchester branch of the NGA or NATSOPA and had completed at least six months of full time membership, some part of which occurred between 1 January 1949 and 31 December 1963. Inclusion of men who entered the branch in later years was considered uninformative due to biological latency periods of several decades known to exist for many malignancies.

History of trade union membership, including dates of joining and leaving the union and movement between branches, was abstracted and transferred to a preprinted data collection form, along with full name, date of birth and at least one address. Occupation and firm of employment on entry to the Manchester branch of the union was also collected.

For a few of the study members, a date of death was given in the branch records. This was used to obtain a copy of the death certificate directly through the Office of Population Censuses and Surveys (OPCS). For most, personal identification details were sent to the National Health Service Central Register (NHSCR) to determine their vital status. The Register returned copies of death certificates for those found to be dead. Dates of emigration were also provided by NHSCR although an appreciable proportion of emigrations are not notified to NHSCR. ${ }^{14}$

The proportion of men not traced by NHSCR or OPCS in London varied by union and year of birth, and were particularly high (22\%) for NATSOPA men born before 1890 . The analyses reported here, therefore, are restricted to those born in 1890 or later; trace rates for whom were $98.4 \%$ for the NGA members and $97 \cdot 2 \%$ for the NATSOPA members.

Coding frames for histories of branch membership were developed in collaboration with the trade unions. Occupational titles were aggregated together if they were judged to refer to the same job. Cause of death coding was carried out by the Office of Population Censuses and Surveys, underlying cause being coded to the International Classification of Diseases (ICD) revision in force at the time of death. If cause of death was not known (two), or had not been coded (11), the death was included in the all cause analyses only.

Comparison of the cohort membership with contemporaneous nominal (cross sectional) lists of branch membership suggested that the cohort was essentially complete. Extensive data validation was carried out, including range and consistency checks and between subject comparisons to eliminate multiple inclusions of the same person.

A worker's contribution to person-time at risk started after they had become a full member of their Manchester branch and had completed six months branch membership, and was ended on the date of death or, for survivors, at the end of study (31 December 1983). Persons known to have emigrated ceased to contribute on the date of their (first) emigration. A few people were known to have died outside England and Wales without having first emigrated. They ceased to contribute to person-time on their date of death, although their death was not counted in the any rate numerator.

The analyses presented cover the follow up period 1950-83. Although available, the 16 deaths in 1949 were not considered as they would have had to have been coded to the 5 th revision of the ICD, resulting in serious problems of comparability with later ICD revisions. Comparisons of mortality in the cohort with those of an external standard were expressed as standardised mortality ratios (SMRs) computed with the personyears computer program. ${ }^{15}$ Expected deaths were obtained by applying age and calendar specific mortalities for men in England and Wales to the corresponding person-years calculated within the program. Calendar period was specified in single years and age in fiveyear bands.

Cause, calendar, and age specific rates for the Manchester area are not available for the full follow up period. Instead, standard rates for England and Wales were derived from the OPCS historic mortality data file. This provides population denominators and counts of deaths by cause, classified by age, year, and ICD revision in force at the time of death. The SMRs based on England and Wales rates were adjusted to take account of the generally higher mortality in the Manchester area by applying correction factors to the expected 
Table 1 Vital status of the traced study sample* (born in 1890 or later) on 31 December 1983 by union

\begin{tabular}{lll}
\hline Vital status & NGA & NATSOPA \\
\hline Alive, at risk & $2934(62 \cdot 4)$ & $2645(58 \cdot 4)$ \\
Deadt & $1657(35 \cdot 2)$ & $1825(40 \cdot 3)$ \\
Emigrated & $111(2 \cdot 4)$ & $60(1 \cdot 3)$ \\
Total & $4702(100 \cdot 0)$ & $4530(100 \cdot 0)$ \\
\hline
\end{tabular}

Figures in parentheses are percentages of union totals.

* Excludes the eight NGA and eight NATSOPA men who were traced but died in 1949.

$t$ Includes two NGA and nine NATSOPA men where cause of death was not ascertained in the † Includes.

\$Includes four NGA men who were known to have died outside of England and Wales without

a prior notification of emigration-contribution to risk ended on date of death.

Table 2 Mortality by cause among NGA men 1950-83 (ages 20-99) compared with England and Wales, with and without adjustment for Manchester County Borough rates

\begin{tabular}{lrcr}
\hline Cause of death (ICD8) & \multicolumn{1}{c}{ Obs } & $S M R_{U}(95 \% C I)$ & $S M R_{A}(95 \% C I)$ \\
\hline All malignant neoplasms (140-209) & 397 & $89(81-99)$ & $71(64-79)$ \\
Stomach (151) & 50 & $96(71-126)$ & $82(61-107)$ \\
Colon (153) & 33 & $120(83-169)$ & $118(81-166)$ \\
Rectum (154). & 21 & $100(62-152)$ & $83(52-127)$ \\
Pancreas (157) & 22 & $118(74-178)$ & $108(68-164)$ \\
Lung (162) & 150 & $82(69-95)$ & $56(47-65)$ \\
Prostate (185) & 22 & $94(59-142)$ & $102(64-155)$ \\
Bladder (188) & 11 & $63(31-113)$ & $58(29-104)$ \\
Il defined + secondary (195-199) & 10 & $64(31-117)$ & $43(21-79)$ \\
Diseases of circulatory system (390-458) & 882 & $101(95-108)$ & $91(85-97)$ \\
Ischaemic heart disease (410-414) & 566 & $103(95-112)$ & $93(85-101)$ \\
Cerebrovascular disease (430-438) & 168 & $100(85-116)$ & $88(75-102)$ \\
Diseases of respiratory system (460-519) & 194 & $76(66-87)$ & $59(51-68)$ \\
Pneumonia (480-486) & 62 & $66(50-84)$ & $67(51-85)$ \\
Bronchitis (490-493) & 109 & $85(70-103)$ & $58(47-70)$ \\
Diseases of digestive system (520-577) & 50 & $106(78-139)$ & $77(56-100)$ \\
Cirrhosis (571) & 11 & $162(81-291)$ & $128(64-229)$ \\
Accidents and violence (800-999) & 39 & $54(39-74)$ & $49(35-67)$ \\
All causes (001-999) & 1657 & $92(88-97)$ & $78(74-82)$ \\
\hline
\end{tabular}

Obs = observed deaths; $\mathrm{SMR}_{\mathrm{U}}=$ standardised mortality ratio not adjusted for Manchester County Borough rates; SMR $=$ standardised mortality ratio adjusted for Manchester County Borough rates.

Table 3 Mortality by cause among NATSOPA men 1950-83 (ages 20-99) compared with England and Wales, with and without adjustment for Manchester County Borough rates

\begin{tabular}{lrrr}
\hline Cause of death (ICD8) & \multicolumn{1}{c}{ Obs } & \multicolumn{1}{c}{$S M R_{U}(95 \% C I)$} & \multicolumn{1}{c}{$S M R_{A}(95 \% C I)$} \\
\hline All malignant neoplasms (140-209) & 509 & $122(112-133)$ & $97(89-106)$ \\
Stomach (151) & 41 & $85(61-115)$ & $72(52-98)$ \\
Colon (153) & 34 & $135(93-188)$ & $132(92-185)$ \\
Rectum (154) & 21 & $108(67-166)$ & $90(56-138)$ \\
Pancreas (157) & 25 & $143(92-210)$ & $131(84-193)$ \\
Lung (162) & 242 & $138(121-157)$ & $94(82-107)$ \\
Prostate (185) & 10 & $50(24-91)$ & $54(26-99)$ \\
Bladder (188) & 18 & $113(67-178)$ & $103(61-163)$ \\
Ill defined + secondary (195-199) & 24 & $164(105-244)$ & $110(70-164)$ \\
Diseases of circulatory system (390-458) & 847 & $107(100-114)$ & $95(88-101)$ \\
Ischaemic heart disease (410-414) & 531 & $104(95-113)$ & $93(85-101)$ \\
Cerebrovascular disease (430-438) & 172 & $172(99-135)$ & $101(86-117)$ \\
Diseases of respiratory system (460-519) & 270 & $120(107-136)$ & $93(82-105)$ \\
Pneumonia (480-486) & 74 & $94(74-118)$ & $95(74-118)$ \\
Bronchitis (490-493) & 166 & $144(122-167)$ & $97(83-113)$ \\
Diseases of digestive system (520-577) & 49 & $114(84-151)$ & $81(60-107)$ \\
Cirrhosis (571) & 8 & $122(53-241)$ & $96(42-189)$ \\
Accidents and violence (800-999) & 66 & $101(79-128)$ & $93(71-117)$ \\
All causes (001-999) & 1825 & $112(106-117)$ & $94(89-98)$ \\
\hline
\end{tabular}

Abbreviations as for table 2 . linear trend in SMRs were calculated with standard methods. ${ }^{16}$

Where appropriate direct comparisons were made of mortality among defined groups within the cohort. This was done by modelling death rates using Poisson regression $^{16}$ in GLIM. ${ }^{17}$ A parallel approach was taken when modelling SMRs.

\section{Results}

Table 1 shows the vital status of the study population at the end of 1983 . Tables 2 and 3 show the SMRs by cause for the NGA and NATSOPA. Mortality ratios based on rates in England and Wales alone are shown in the column $\mathrm{SMR}_{\mathrm{U}}$, and those calculated with expected deaths adjusted for Manchester County Borough rates are shown in the column $\mathrm{SMR}_{\mathrm{A}}$. The causes listed are those for which there were a minimum of 10 observed deaths in at least one of the two tables.

All cause mortality is below that for England and Wales for the NGA, whereas for NATSOPA it is above; in both the $95 \%$ CIs for $S_{M} R_{U}$ exclude 100. Adjustment for the higher rates in the Manchester area reduces the all causes SMRs for both unions by around $15 \%$, such that both have an $S_{M R}$ that is below 100 with CIs that again exclude 100.

The SMRs by cause show a heterogeneous picture. Notable features include the high $S M R_{U}$ for lung cancer among the NATSOPA men, by contrast with the low $S M R_{U}$ in the NGA. Bronchitis SMRs tend to mirror this pattern. The $S M R_{U}$ for circulatory disease, and ischaemic heart disease in particular, are close to 100 in both unions.

In general, adjustment for Manchester rates results in a reduction in cause specific SMRs. As the difference between mortality in Manchester and nationally varies by cause, so does the effect of adjustment for Manchester. Adjustment brings about particularly large reductions in mortality ratios for lung cancer, cancers of ill defined and secondary sites, bronchitis, and diseases of the digestive system. The pronounced excess of deaths from lung cancer in NATSOPA, disappears on adjustment for area. In a few instances, such as prostate cancer, adjustment results in a small increase in the mortality ratio. Only nine of the $S M R_{A}$ s in tables 2 and 3 are above 100.

Table 4 shows direct comparisons of the mortality rates in NATSOPA with those in the NGA. Mortality in NATSOPA is expressed as a ratio relative to that in the NGA with adjustment for age and calendar period. These rate ratios show a similar picture to that obtained by comparing the corresponding SMRs. With the exception of stomach cancer, rates in NATSOPA are higher than those in the NGA. For lung cancer there is a $70 \%$ excess in NATSOPA compared with the NGA. It is notable, however, that the ischaemic heart disease ratio is only just above unity.

The membership of each trade union

on the variance of $\log$ SMR being the reciprocal of the observed number of deaths. ${ }^{16} \chi^{2}$ statistics for heterogeneity and 
Table 4 Mortality among NATSOPA men relative to those in the NGA for major causes of death 1950-83 (ages 20-99) adjusted for age and calendar period

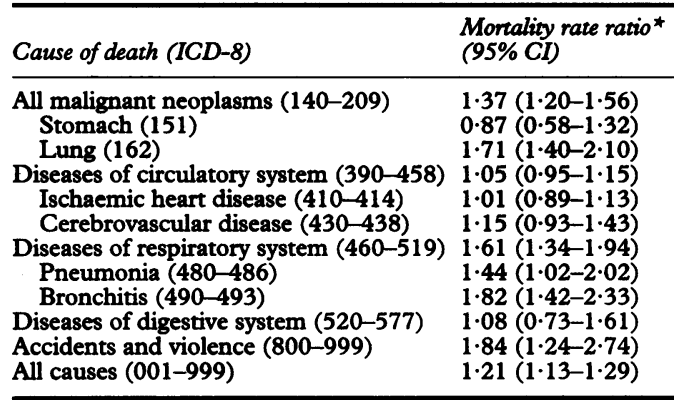

*Mortality among NATSOPA men expressed relative to that among NGA men, adjusted for age (in 14 categories; 20-, 25-, . 85) and calendar period (in 7 categories; 1950-, 1955-, years as the OFFSET term. $95 \%$ CIs estimated from standard errors of parameter estimates.

branch covered a range of diverse occupations. Tables 5 and 6 show the all cause SMRs for the important occupational categories in the NGA and NATSOPA. The NGA occupations (table 5) may be divided into those principally associated with work in newspaper production (NGA occupations 1-2), and those with work in general printing (NGA occupations 3-6). Men in NGA occupations 1 and 3 ran the printing presses, whereas men in NGA occupations 2 and 4 were compositors who converted original copy into a form suitable for producing printing plates. Readers (NGA occupation 5) were concerned with checking and correcting copy and proofs. The all cause SMRs given in table 5 show little variation between the main NGA occupations (1-5). The SMRs for the workers whose occupation was not stated are notably higher than any other category. Most in NATSOPA (table 6) worked in occupations in newspaper production (NATSOPA occupations 1-5). Machine assistants (NATSOPA occupation 1), worked alongside NGA rotary machine managers (NGA occupation 1 ; table 5) operating newspaper rotary presses. Publishing room men (NATSOPA occupation 2) took freshly printed newspapers and wrapped and labelled them for dispatch to retailers and wholesalers. The publishing room in which they worked was separate from the pressroom where the newspapers were printed, the two being connected through conveyor belts. Men in wholesale newspaper distribution (NATSOPA occupation 6) were employed in premises that were separate from the printing plants. The SMRs in table 6 show little variation across occupation, with the exception of newspaper clerical workers (NATSOPA occupation 5), who have strikingly low mortality. As with the NGA the NATSOPA workers whose occupation was not stated have the highest mortality.

As a particular focus of the study was on the possible occurrence of occupationally related cancers in the industry, table 7 shows mortality ratios for a range of malignancies in the four largest categories of printing production workers with well characterised workplace environments. Men in the NATSOPA occupation category 4, other production, maintenance and ancillary, and other similar groups, are not included in the table as they are comprised of men subject to very diverse and heterogeneous exposures.

Many of the mortality ratios shown in table 7 are based on fewer than 10 observed deaths, hence the very wide $95 \%$ CIs. The most striking result is the very high $S_{M} R_{U}$ for lung cancer among NATSOPA machine assistants, which has CIs that exclude 100 . Adjustment for Manchester rates, however, produces an $\mathrm{SMR}_{\mathrm{A}}$ that is considerably lower. The only other instance in table 7 of a raised SMR in which the CIs exclude 100 is for malignant neoplasms of the brain and central nervous system among NATSOPA publishing room men.

Although not shown in the tables, two occupational groups had SMRs for malignant

Table 5 All cause mortality by occupation on entry to the Manchester branch of NGA 1950-83 (ages 20-99) compared with England and Wales, with and without adjustment for Manchester County Borough rates

\begin{tabular}{|c|c|c|c|c|c|}
\hline \multicolumn{2}{|c|}{ Occupation on entry to Manchester branch } & \multirow{2}{*}{$\begin{array}{c}\text { Men }(n) \\
159 \\
433 \\
1307 \\
2522 \\
106 \\
117 \\
66\end{array}$} & \multirow{2}{*}{\begin{tabular}{r|} 
Obs \\
103 \\
206 \\
380 \\
842 \\
66 \\
38 \\
22
\end{tabular}} & \multirow{2}{*}{$\begin{array}{c}S M R_{U}(95 \% C I) \\
94(77-114) \\
89(77-102) \\
94(85-104) \\
92(85-98) \\
84(65-106) \\
103(72-139) \\
144(90-218)\end{array}$} & \multirow{2}{*}{$\begin{array}{c}S M R_{A}(95 \% C I) \\
82(66-99) \\
76(66-87) \\
79(71-87) \\
77(72-83) \\
73(56-92) \\
86(60-116) \\
118(74-179)\end{array}$} \\
\hline $\begin{array}{l}1 \\
2 \\
3 \\
4 \\
5 \\
6 \\
7\end{array}$ & $\begin{array}{l}\text { Rotary machine manager } \\
\text { Linotype operator } \\
\text { Machine manager (not otherwise specified) } \\
\text { Compositor, other } \\
\text { Reader } \\
\text { Other stated occupations } \\
\text { Not stated }\end{array}$ & & & & \\
\hline
\end{tabular}

Abbreviations as for table 2 .

Table 6 All cause mortality by occupation on entry to the Manchester branch of NATSOPA 1950-83 (ages 20-99) compared with England and Wales, with and without adjustment for Manchester County Borough rates

\begin{tabular}{|c|c|c|c|c|c|}
\hline \multicolumn{2}{|c|}{ Occupation on entry to Manchester branch } & \multirow[b]{2}{*}{$\begin{array}{c}\text { Men }(n) \\
1322 \\
532 \\
227 \\
854 \\
559 \\
185 \\
604 \\
114 \\
141\end{array}$} & \multirow[b]{2}{*}{\begin{tabular}{r|} 
Obs \\
576 \\
234 \\
81 \\
335 \\
126 \\
109 \\
220 \\
36 \\
108
\end{tabular}} & \multirow[b]{2}{*}{$\begin{array}{l}S M R_{U}(95 \% C I) \\
116(106-126) \\
113(99-128) \\
113(89-140) \\
119(106-132) \\
79(65-93) \\
101(83-122) \\
112(97-127) \\
108(76-149) \\
135(110-163)\end{array}$} & \multirow[b]{2}{*}{$\begin{array}{c}S M R_{A}(95 \% C I) \\
97(90-106) \\
95(83-108) \\
94(74-116) \\
99(89-110) \\
66(55-78) \\
86(70-103) \\
93(81-106) \\
90(63-125) \\
116(95-140)\end{array}$} \\
\hline $\begin{array}{l}1 \\
2 \\
3 \\
4 \\
5 \\
6 \\
7 \\
8\end{array}$ & $\begin{array}{l}\text { Machine assistant } \\
\text { Publishing room } \\
\text { Reader or composing room assistant } \\
\text { Other production, maintenance and ancillary } \\
\text { Clerical } \\
\text { Wholesale news distribution } \\
\text { General printing } \\
\text { Ink manufacture } \\
\text { Not stated }\end{array}$ & & & & \\
\hline
\end{tabular}

Abbreviations as for table 2 . 
Table 7 Mortality from selected malignant neoplasms in four major occupational groups, 1950-83, ages 20-99, compared with England and Wales, with and without adjustment for Manchester County Borough rates

\begin{tabular}{|c|c|c|c|c|c|c|c|c|c|c|c|c|}
\hline \multirow{2}{*}{$\begin{array}{l}\text { Site of malignant } \\
\text { neoplasm } \\
\text { (ICD-8) }\end{array}$} & \multicolumn{3}{|c|}{ NGA machine managers } & \multicolumn{3}{|c|}{ NGA compositors } & \multicolumn{3}{|c|}{ NATSOPA machine assistants } & \multicolumn{3}{|c|}{ NATSOPA publishing room men } \\
\hline & Obs & $\begin{array}{l}S M R_{U} \\
(95 \% C I)\end{array}$ & $\begin{array}{l}S M R_{A} \\
(95 \% C I)\end{array}$ & Obs & $\begin{array}{l}S M R_{U} \\
(95 \% C I)\end{array}$ & $\begin{array}{l}S M R_{A} \\
(95 \% C I)\end{array}$ & Obs & $\begin{array}{l}S M R_{U} \\
(95 \% \mathrm{CI})\end{array}$ & $\begin{array}{l}S M R_{A} \\
(95 \% C I)\end{array}$ & Obs & $\begin{array}{l}S M R_{U} \\
(95 \% C I)\end{array}$ & $\begin{array}{l}S M R_{A} \\
(95 \% C I)\end{array}$ \\
\hline $\begin{array}{l}\text { Oesophagus } \\
(150)\end{array}$ & 3 & $\begin{array}{l}107 \\
(22-314)\end{array}$ & $\begin{array}{l}87 \\
(18-254)\end{array}$ & 6 & $\begin{array}{l}98 \\
(36-213)\end{array}$ & $\begin{array}{l}79 \\
(29-172)\end{array}$ & 5 & $\begin{array}{l}148 \\
(48-346)\end{array}$ & $\begin{array}{l}120 \\
(39-280)\end{array}$ & 3 & $\begin{array}{l}216 \\
(45-632)\end{array}$ & $\begin{array}{l}175 \\
(36-512)\end{array}$ \\
\hline $\begin{array}{l}\text { Stomach } \\
\quad(151)\end{array}$ & 12 & $\begin{array}{l}103 \\
(53-181)\end{array}$ & $\begin{array}{l}88 \\
(45-153)\end{array}$ & 27 & $\begin{array}{l}102 \\
(67-148)\end{array}$ & $\begin{array}{l}87 \\
(57-126)\end{array}$ & 10 & $\begin{array}{l}68 \\
(32-125)\end{array}$ & $\begin{array}{l}58 \\
(28-106)\end{array}$ & 8 & $\begin{array}{l}129 \\
(56-254)\end{array}$ & $\begin{array}{l}110 \\
(47-217)\end{array}$ \\
\hline $\begin{array}{l}\text { Colon } \\
\text { (153) }\end{array}$ & 8 & $\begin{array}{l}129 \\
(56-254)\end{array}$ & $\begin{array}{l}126 \\
(55-249)\end{array}$ & 20 & $\begin{array}{l}142 \\
(87-220)\end{array}$ & $\begin{array}{l}140 \\
(85-216)\end{array}$ & 12 & $\begin{array}{l}157 \\
(81-275)\end{array}$ & $\begin{array}{l}154 \\
(80-270)\end{array}$ & 4 & 126 & $\begin{array}{l}123 \\
(34-316)\end{array}$ \\
\hline $\begin{array}{r}\text { Rectum } \\
(154)\end{array}$ & 5 & 106 & $\begin{array}{l}88 \\
(28-204)\end{array}$ & 12 & $(58-195)$ & $\begin{array}{l}93 \\
(48-162)\end{array}$ & 9 & $\begin{array}{l}152 \\
(70-289)\end{array}$ & $\begin{array}{l}127 \\
(58-240)\end{array}$ & 1 & $\begin{array}{l}41 \\
(1-228)\end{array}$ & $(1-190)$ \\
\hline $\begin{array}{l}\text { Liver and gall bladder } \\
(156)\end{array}$ & 1 & $\begin{array}{l}83 \\
(2-461)\end{array}$ & $\begin{array}{l}66 \\
(2-366)\end{array}$ & 4 & $\begin{array}{l}153 \\
(42-391)\end{array}$ & 121 & 2 & $\begin{array}{l}138 \\
(17-477)\end{array}$ & 109 & 1 & $\begin{array}{l}168 \\
(4-933)\end{array}$ & $\begin{array}{l}133 \\
(3-741)\end{array}$ \\
\hline $\begin{array}{c}\text { Pancreas } \\
\text { (157) }\end{array}$ & 6 & 139 & $(47-276)$ & 13 & $(72-232)$ & $(66-213)$ & 6 & 114 & 105 & 2 & $\begin{array}{l}92 \\
(11-331)\end{array}$ & 84 \\
\hline Lung & 37 & $\begin{array}{l}87 \\
(61-120)\end{array}$ & $\begin{array}{l}59 \\
(42-81)\end{array}$ & 77 & $\begin{array}{l}82 \\
(64-101)\end{array}$ & $\begin{array}{l}56 \\
(44-69)\end{array}$ & 94 & 179 & $(98-148)$ & 27 & $\begin{array}{l}122 \\
(80-177)\end{array}$ & $\begin{array}{l}83 \\
(55-121)\end{array}$ \\
\hline $\begin{array}{r}\text { Prostate } \\
(185)\end{array}$ & 6 & $(46-270)$ & $\begin{array}{l}135 \\
(50-294)\end{array}$ & 13 & $\begin{array}{l}110 \\
(59-188)\end{array}$ & 120 & 4 & $\begin{array}{l}65 \\
(18-167)\end{array}$ & $\begin{array}{l}71 \\
(19-181)\end{array}$ & 1 & $\begin{array}{l}39 \\
(1-215)\end{array}$ & $\begin{array}{l}42 \\
(1-234)\end{array}$ \\
\hline $\begin{array}{r}\text { Bladder } \\
(188)\end{array}$ & 1 & $\begin{array}{l}26 \\
(1-145)\end{array}$ & $\begin{array}{l}24 \\
(1-133)\end{array}$ & 7 & $\begin{array}{l}79 \\
(32-162)\end{array}$ & $\begin{array}{l}73 \\
(29-150)\end{array}$ & 6 & $\begin{array}{l}124 \\
(45-269)\end{array}$ & $\begin{array}{l}114 \\
(42-248)\end{array}$ & 1 & $\begin{array}{l}49 \\
(1-273)\end{array}$ & $\begin{array}{l}45 \\
(1-251)\end{array}$ \\
\hline $\begin{array}{l}\text { Kidney } \\
(189)\end{array}$ & 2 & $\begin{array}{l}120 \\
(15-435)\end{array}$ & $(14-430)$ & 3 & $\begin{array}{l}84 \\
(17-246)\end{array}$ & $\begin{array}{l}83 \\
(17-244)\end{array}$ & 1 & $\begin{array}{l}51 \\
(1-282)\end{array}$ & $\begin{array}{l}50 \\
(1-280)\end{array}$ & 1 & $\begin{array}{l}123 \\
(3-687)\end{array}$ & $(3-680)$ \\
\hline $\begin{array}{l}\text { Brain and other CNS . } \\
(191-192)\end{array}$ & 1 & $\begin{array}{l}41 \\
(1-229)\end{array}$ & $\begin{array}{l}42 \\
(1-232)\end{array}$ & 6 & $\begin{array}{l}123 \\
(45-268)\end{array}$ & $\begin{array}{l}124 \\
(46-271)\end{array}$ & 2 & $\begin{array}{l}76 \\
(9-273)\end{array}$ & $\begin{array}{l}76 \\
(9-276)\end{array}$ & 4 & $\begin{array}{l}370 \\
(101-947)\end{array}$ & $\begin{array}{l}374 \\
(102-957)\end{array}$ \\
\hline $\begin{array}{l}\text { Ill defined and } \\
\text { secondary } \\
(195-199)\end{array}$ & 3 & $\begin{array}{l}81 \\
(17-236)\end{array}$ & $\begin{array}{l}54 \\
(11-158)\end{array}$ & 5 & $\begin{array}{l}62 \\
(20-145)\end{array}$ & $\begin{array}{l}42 \\
(14-97)\end{array}$ & 4 & $\begin{array}{l}93 \\
(25-238)\end{array}$ & $\begin{array}{l}62 \\
(17-160)\end{array}$ & 2 & $\begin{array}{l}111 \\
(13-400)\end{array}$ & $\begin{array}{l}74 \\
(9-269)\end{array}$ \\
\hline $\begin{array}{c}\text { Non-Hodgkin's } \\
\text { lymphoma } \\
(200,202)\end{array}$ & 2 & $\begin{array}{l}121 \\
(15-437)\end{array}$ & $\begin{array}{l}121 \\
(15-437)\end{array}$ & 4 & $\begin{array}{l}117 \\
(32-299)\end{array}$ & $\begin{array}{l}117 \\
(32-299)\end{array}$ & 4 & $\begin{array}{l}216 \\
(59-554)\end{array}$ & $\begin{array}{l}216 \\
(59-554)\end{array}$ & 2 & $\begin{array}{l}268 \\
(32-968)\end{array}$ & $\begin{array}{l}268 \\
(32-968)\end{array}$ \\
\hline $\begin{array}{l}\text { Leukaemia } \\
\qquad(204-208)\end{array}$ & 1 & $\begin{array}{l}39 \\
(1-219)\end{array}$ & $\begin{array}{l}45 \\
(1-252)\end{array}$ & 3 & $\begin{array}{l}55 \\
(11-160)\end{array}$ & $\begin{array}{l}63 \\
(13-184)\end{array}$ & 2 & $\begin{array}{l}69 \\
(8-248)\end{array}$ & $\begin{array}{l}79 \\
(10-285)\end{array}$ & 2 & $\begin{array}{l}164 \\
(20-593)\end{array}$ & $\begin{array}{l}189 \\
(23-681)\end{array}$ \\
\hline
\end{tabular}

Abbreviations as for table 2.

neoplasms of the buccal cavity and pharynx (excluding lip and salivary glands), that were significantly raised at the $5 \%$ level. NATSOPA men who entered the branch in the editorial group had an $\mathrm{SMR}_{\mathrm{U}}$ of 1053 (95\% CI 128-3803) based on two deaths, and those entering in the clerical group had an $S_{M R}$ of 638 (95\% CI 132-1864) based on three deaths. Adjustment for Manchester rates reduced both mortality ratios, resulting in $S_{M R}$ S of $667(95 \%$ CI 81-2408) for editorial and 405 (95\% CI 84-1183) for clerical workers.

\section{Discussion}

\section{OCCUPATIONAL MORTALITY}

The initial reason to set up the cohort study was concern that there was an occupational risk of bladder cancer in the industry. The results of the study are generally reassuring on this question. Overall there is no evidence of a generally increased risk. There was also no strong evidence of an increased risk in any of the four specific occupational groups examined. It should be noted, however, that the study lacked statistical power at this level of occupational disaggregation. The wide confidence intervals for NATSOPA machine assistants working in newspapers showed that the existence of an increased risk of the order of 2.5 compared with the general population cannot be excluded.

The evidence for an increased risk of bladder cancer among printing workers from other studies is not conclusive. Two proportional mortality studies of men in general printing have found proportional mortality ratios of $140^{4}$ and $108,{ }^{18}$ whereas two cohort studies of newspaper printing machine operators in the United States reported SMRs of $85^{19}$ and $149 .^{20}$ Case-control studies of bladder cancer have examined the risks associated with work in the printing industry, although the occupational groups defined have often been so heterogeneous that they make the results difficult to interpret. The two casecontrol studies that have defined their exposed category as composed of those who worked on or in the immediate vicinity of printing presses both found increased risks; an odds ratio of 3.1 (95\% CI 1.4-6.8) was found in a study from West Yorkshire, ${ }^{21}$ whereas data from Missouri showed an odds ratio of $3 \cdot 1(95 \%$ CI $1 \cdot 1-8 \cdot 9) .^{22}$

One of the most striking findings of our study was the raised SMR for lung cancer among NATSOPA machine assistants. Compared with England and Wales, this group had an SMR of $179 \quad(95 \%$ CI 144-218), which was reduced to 122 (95\% CI 98-148) on adjustment for rates in Manchester. The possibility that these figures reflected an occupational risk of lung cancer among newspaper printers has been investigated in a nested case-control study. ${ }^{23}$

The risk of colorectal cancer among men working in various occupations in the printing industry has been investigated in a number of studies. Increased risks have been found for press operators in general printing in the United States, ${ }^{418}$ printers in New Zealand, ${ }^{24}$ and printing press operators in Missouri. ${ }^{25}$ Other studies, however, do not find an increased risk, ${ }^{7}$ including the two largest other cohort studies of newspaper printing 
press operators. ${ }^{19} 20$ The results of our study provide some support for the existence of an occupational risk of cancer of the colon but less for cancer of the rectum.

Apart from lung cancer among NATSOPA machine assistants, the only other SMR (table 7) where the lower confidence limit is above 100 is for malignant neoplasms of the brain and other sites in the central nervous system among NATSOPA publishing room men. Because of the large number of multiple comparisons, this seemingly significant excess may be due to chance alone. A case-control study of this site based on cancer registry data from Missouri ${ }^{26}$ found an odds ratio of $2 \cdot 8$ (95\% CI 1.0-8.3) among white men with a history of work in the printing and publishing industry. Studies of mortality in the printing industry ${ }^{18}{ }^{20}$ do not support the existence of such an association.

The excesses of cancers of the buccal cavity and pharynx found among nonproduction workers (NATSOPA editorial and clerical staff) are not very informative despite being numerically large, as they are based on two and three deaths. It is interesting to note, however, that seven of the nine published studies that provided data on the risk of cancer of the buccal cavity and pharynx among printing workers reported increased risks, which in five instances were statistically significant at the $5 \%$ level. In a multisite casecontrol study of occupation among cancer patients in New York, ${ }^{27}$ the heterogenous group of compositors, typesetters, electrotypers, pressmen, and other printing occupations were found to have a risk of 2.59 (95\% CI 1.04-6.45), relative to men who had mainly worked in clerical occupations. A proportional mortality study of newspaper pressmen in the United States ${ }^{7}$ reported a proportional mortality ratio of 237 (95\% CI 108-450), whereas a large cohort study of New York newspaper pressman ${ }^{19}$ reported an SMR of 249 (95\% CI 145-399). Two different analyses of routine data from the United States also reported statistically significant excesses of cancer of the buccal cavity and pharynx among pressmen and plate printers ${ }^{28}$ and printers. ${ }^{29}$ Non-significant excesses were found for malignant neoplasms of the buccal cavity and pharynx in a proportional mortality study of general print workers in New York, ${ }^{18}$ and for malignant neoplasm of the tonsil among newspaper printers in London. ${ }^{5}$ A study of workers in the United States Government Printing Office 4 and of Los Angeles newspaper pressmen ${ }^{20}$ both reported finding fewer deaths from this cause than expected.

With the intriguing exception of our study, these excesses occur principally among men directly engaged in the printing process itself. This gives plausibility to the contention that there may be a real association between printing and risk of cancer of the buccal cavity and pharynx. The failure to show an increased risk among men who operate printing presses in this study (NGA machine managers and NATSOPA machine assistants) may be a chance effect reflecting a lack of statistical power-the CIs for the SMRs are very wide and consistent with large effects.

Future investigations of the health risks among workers in the printing industry should have regard to two important points. Firstly, the technology and the associated exposures in the workplace have undergone important changes in Britain and elsewhere over the past decade. Newspaper printing has moved from its traditional use of rotary letterpress machines to offset lithography. It will be sometime before it is possible to assess the long term effects of these new processes on the health of printing workers. The second point concerns the very imprecise way in which epidemiologists have tended to define printers. This term has been used to refer to people engaged in any aspect of the printing process from compositors to printing press operators. Moreover, no distinction is usually drawn between people working in newspapers as opposed to general printing. This lack of precision is important as depending upon workers' particular occupations and the sector of the industry they work in, their workplace environments and exposures are very different. A broad aggregate category of "printer" that encompasses anyone in the industry will not produce informative results. Even in case-control studies where specific occupational exposures may be rare, the temptation to combine everyone in the industry together should be resisted.

EFFECTS OF SKILL AND STATUS ON MORTALITY Aside from any specific occupational risk factors that may have influenced mortality differences within the study population, there seems to have been a strong socioeconomic component underlying the general mortality differences between the NGA and NATSOPA.

For all causes the mortality of NATSOPA men was $21 \%$ higher than that in the NGA. It is unlikely that this excess could be due to biased ascertainment of deaths, as the extent of this excess varies considerably by cause of death. For instance, whereas there is virtually no difference in mortality from ischaemic heart disease in the two unions, mortalities for respiratory diseases are some $60 \%$ higher among NATSOPA men than among the NGA. The very heterogenous nature of the work environments of men within each union also counts against excess mortality in NATSOPA being explained purely by occupational influences.

One explanation of the contrast in mortality between the unions may be provided by differences in the skill and status of their membership. The NGA was the traditional craft union of the industry, whose members served strictly regulated apprenticeships, and occupied the most skilled jobs, reflected in their greater status and wages. By contrast membership of NATSOPA did not need to serve an apprenticeship, the union covering a much wider range of skill levels in the industry. Even where NATSOPA men 
worked alongside NGA men, as in newspaper production, the first were referred to as machine assistants whereas the second were known as machine managers. The wages of these two groups were different. For instance, in 1961 the weekly wage of NGA machine managers in newspapers was $£ 35$, whereas for NATSOPA machine assistants it was $£ 29 .{ }^{11}$ Wage differentials of this sort between men in the two unions persisted during the entire study period.

Many NATSOPA men in the study were in semiskilled or unskilled jobs such as packing newspapers, cleaning production areas, and ancillary jobs including those of commissionaires and messengers. In the Registrar General's social classes, these jobs belonged mainly in class IV (semiskilled manual) or class $\mathrm{V}$ (unskilled manual). By contrast allof the NGA men in the study who were employees would have belonged to class IIIM (skilled manual), whereas a few of the NGA men ran their own printing businesses.

Given these facts, it is interesting to note that the sizes of the NATSOPA to NGA mortality ratios (table 4) are similar to those seen between classes V and IIIM in the 1971 Decennial Supplement on Occupational Mortality. ${ }^{30}$ The V to IIIM ratio for diseases of the circulatory system was $1 \cdot 11$, compared with 1.05 for the NATSOPA to NGA ratio. For diseases of the respiratory system the $\mathrm{V}$ to IIIM ratio was 1.76 compared with 1.61 for the NATSOPA to NGA ratio, whereas the equivalent ratios for mortality from accidents and violence were $2 \cdot 10$ and $1 \cdot 84$. The most important exception is for lung cancer where the between union ratio $(1.71)$ is considerably greater than the V to IIIM ratio $(1 \cdot 25)$. Overall, however, the cause specific pattern of differences between the unions is similar to that seen between classes.

That socioeconomic factors may play a part in accounting for the union differences in mortality among men employed in a single industry has parallels in the findings of other studies of employed populations. For instance, a study of workers from the $\mathrm{Du}$ Pont company ${ }^{31}$ found considerable differences in morbidity from chronic diseases that were related to income level. In the Whitehall study of British civil servants, large differences in mortality by civil service grade have been found. ${ }^{32}$

The existence of appreciable socioeconomic mortality differences between groups of manual workers in the same industry, as suggested here, means that internal comparisons of exposed and unexposed groups of workers that are commonly used in occupational epidemiology should be interpreted with caution. Such comparison, even within one industry, may reflect the greater influence of way of life over that of the work environment. ${ }^{33}$

I thank St Peter's Hospitals and the Institute of Urology for their initial support; officers and members of the printing trade unions especially Eve Horwood, Cyril Brown, Don
Brown, Ken Heseltine, Bud Hudspith, Arthur Perrin, and John Willats; Barbara Lowe who carried out the main data collection so painstakingly; and Gillian Ashe, Bonita Peachy, collection so painstakingly; and Gillian Ashe, Bonita Peachy, Judith Randall, Helen Louise Taylor, and Terry White who did the other clerical work; Gifford Mann and Pat Edwards at
the Health and Safety Executive; colleagues John Fox, Val the Health and Safety Executive; colleagues John Fox, Val
Beral, Lucy Carpenter, George Davey Smith, Allison Douglas, Martin Gardner, Geoffrey Rose, and Peter Smith The study was largely funded by the Cancer Research Campaign, with contributions from the trades unions, employers organisations, and the Health and Safety Executive. The study formed the basis of my $\mathrm{PhD}$ thesis (University of London, 1991)

1 Wynder EL, Goldsmith R. The epidemiology of bladder cancer: a second look. Cancer 1977;40:1246-68.

2 Wynder EL, Onderdonk J, Mantel N. An epidemiological investigation of cancer of the bladder. Cancer 1963 16:1388-407.

3 Cole P, Hoover R, Friedell GH. Occupation and cancer of the lower urinary tract. Cancer 1972;29:1250-60.

4 Greene MH, Hoover RN, Eck RL, Fraumeni JF. Cancer mortality among printing plant workers. Environ Res 1979;20:66-73.

5 Greenberg $M$. A proportional mortality study of a group of newspaper workers. Br f Ind Med 1972;29:15-20.

6 Moss E, Scott TS, Atherley GRC. Mortality of newspaper workers from lung cancer and bronchitis 1952-66. Br $\mathcal{F}$ Ind Med 1972;29:1-14.

7 Lloyd JW, Decoufle P, Salvin LG. Unusual mortality experience of printing pressmen. F Occup Med 1977;19. 543-50.

8 Milvy P, Kay K. Mutagenicity of 19 major graphic arts and printing dyes. $\mathcal{F}$ Toxicol Environ Health 1978 4:31-6.

9 Kay K. Toxicological evaluation of chemicals used in the printing and printing inks industries. In: Ayer FA, ed. Environmental aspects of chemical use in printing operations. Conference proceedings, September 1975. Washington: Office of Toxic Substances, Environmental Protection Affice of Toxic Substancy, 1976:111-39.

10 Health and Safety Executive. Health and SafetyManufacturing and Service Industries 1977. London HMSO, 1979.

11 Royal Commission on the Press. Industrial relations in the National Newspaper Industry. A report by the Advisory Conciliation and Arbitration Service. London: HMSO, 1976. (Research series 1.)

12 Musson AE. The typographical association: origins and history up to 1949. London: Oxford University Press, 1954.

13 Moran J. NATSOPA: seventy five years. The National Society of Operative Printers and Assistants, (1889-1964). Society of Operative Printers

14 Darby SC, O'Hagan JA, Kendall GM, Doll R, Fell TP Muirhead CR. Completeness of follow up in a cohort study of mortality using the United Kingdom National Health Service Central Registers and records held by the Department of Social Security. $\mathcal{f}$ Epidemiol Community Health 1991;45:65-70.

15 Coleman M, Douglas A, Peto J. Cohort study analysis with a FORTRAN computer program. Int $\mathcal{f}$ Epidemiol 1986;15:134-7.

16 Breslow NE, Day NE. Statistical methods in cancer research. Vol 2. The design and analysis of cohort studies. Lyon: International Agency for Research on Cancer, 1987. (Sci publ No 82.)

17 Baker RJ, Nelder JA. The GLIM system: release 3. Oxford: Numerical Algorithms Group, 1978.

18 Zoloth SR, Michaels DM, Villalbi JR, Lacher M. Patterns of mortality among commercial pressmen. $\mathcal{F}$ Natl Cancer Inst 1986;76:1047-51.

19 Nicholson WJ, Seidmen H, Hoos D, Selikoff IJ. The mortality experience of New York City newspaper pressmen,
1950-1976. New York: Environmental Sciences Laboratory, Mount Sinai School of Medicine, 1981.

20 Paganini-Hill A, Glazer E, Henderson BE, Ross RK. Cause-specific mortality among newspaper web pressmen. F Occup Med 1980;22:542-4.

21 Cartwright RA. Occupational bladder cancer and cigarette smoking in West Yorkshire. Scand $f$ Work Environ Health 1982;8:79-82.

22 Brownson RC, Chang JC, Davis JR. Occupation, smoking, and alcohol in the epidemiology of bladder cancer. Am f Public Health 1987;77:1298-300.

23 Leon DA, Thomas P, Hutchings S. Lung cancer among newspaper printers exposed to ink mist: a study of trade union members in Manchester, England. Occup Environ Med 1994;51:87-94.

24 Pearce NE, Howard JK. Occupation, social class and male cancer mortality in New Zealand, 1974-78. Int $\mathcal{F}$ Epidemiol 1986;15:456-62.

25 Brownson RC, Zahim SH, Chang JC, Blair A Occupational risk of colon cancer. An analysis by anatomic subsite. Am $\mathcal{f}$ Epidemiol 1989;130:675-87.

26 Brownson RC, Reif JS, Chang JC, Davis JR. An analysis of occupational risks for brain cancer. Am $f$ Public Health 1990;80:169-72. 
27 Decoufle P, Stanislawczyk K, Houten L, Bross IDJ, Viadana $\mathrm{E}$. A retrospective survey of cancer in relation to occupation. Cincinnati: US Department of Health, Education and Welfare, National Institute for Occupational Safety and Health, 1977

28 Dubrow R, Wegman DH. Cancer and occupation in Massachusetts: a death certificate study. Am $\mathscr{f}$ Ind Med 1984;6:207-30.

29 Williams RR, Stegens NL, Goldsmith JR. Associations of cancer site and type with occupation and industry from the third national cancer survey interview. $₹$ Natl Cancer Inst 1977;59:1147-85.
30 Office of Population Censuses and Surveys. Occupational mortality. The Registrar General's decennial supplement for England and Wales, 1970-72. London: HMSO, 1978. (Series DS No 1.)

31 Pell S, D'Alonzo CA. Chronic disease morbidity and income level in an employed population. Am $\mathcal{f}$ Public Health 1970;60:116-29.

32 Marmot MG, Shipley MJ, Rose G. Inequalities in deathspecific explanations of a general pattern? Lancet 1984;i: specific

33 Fox AJ, Adelstein AM. Occupational mortality: work or way of life? ₹ Epidemiol Community Health 1978;32:73-8.

\section{NOTICE}

\section{Viral hepatitis conference}

Occupational Health Review (OHR) is to host a major one day conference on "Viral hepatitis-issues for employers", in London this spring. This independent conference will provide a scientific update on viral hepatitis-including explanations of transmission, prognosis and carrier status-and will discuss employers' legal duties, insurance aspects, identification of high risk occupations, vaccination, testing, the position of low risk personnel, viral epidemiology, counselling, the Department of Health guidelines, confidentiality, and ethics.

To be held in central London on Friday 18 March 1994, the conference will include presentations by leading specialists in the field. Chaired by OHR editor Dr John Ballard, the speakers are: Professor Paul Griffiths, Royal Free Hospital School of Medicine; Vivienne Harpwood, Cardiff Law School, Dr Julia Heptonstall, Public Health Laboratory Service; Dr Eoin Hodgson, University of Oxford occupational health service; Dr James Nokes, Oxford University; and Dr Anne Cockcroft, Royal Free
Hospital occupational health department.

Viral hepatitis is one of the most important issues on the occupational health agenda. Not only must employers consider their statutory obligations regarding the possible vaccination of at-risk employees, there are additional civil liability concerns where, particularly in the health care sectors, patients may be at risk from health care staff. Recent media attention on hepatitis risks from surgical intervention has galvanised public concern, and organisations in both the private and public sector need policies in place to fulfil their legal duties and to reassure their employees and the public. "Viral hepatitis-issues for employers" is a conference designed to raise these issues and provide delegates with independent information relevant to the development of hepatitis policies for their own organisations.

For further information, contact Annabel McLaughlin, IRS Training, 18-20 Highbury Place, London N5 1QP (tel: 071-354 5858; fax: 071-226 8618), or John Ballard, editor, OHR. 